\title{
Field evaluation of 3-hydroxy-2-hexanone and ethanol as attractants for the cerambycid beetle pest of vineyards, Xylotrechus arvicola
}

\section{Álvaro Rodríguez-González, ${ }^{a *}{ }^{*}$ Esteban Sánchez-Maíllo, ${ }^{b}$ Horacio J Peláez, ${ }^{c}$ Manuel González-Núñez, ${ }^{d}$ David R Halle and Pedro A Casquero ${ }^{a}$}

\begin{abstract}
BACKGROUND: The beetle Xylotrechus arvicola (Coleoptera: Cerambycidae) is a serious pest of vineyards in the Iberian Peninsula. In previous work, the male beetles, but not females, were shown to produce $(R)$-3-hydroxy-2-hexanone, and female beetles were attracted to this compound in a laboratory bioassay. In this study, release rates of 3-hydroxy-2-hexanone from different dispensers were measured in the laboratory, and the attractiveness of these to $X$. arvicola adults was determined in trapping tests in three traditional wine-growing regions in Spain.

RESULTS: As a result of laboratory experiments, for field experiments 3-hydroxy-2-hexanone was formulated as $100 \mu \mathrm{L}$ in a polyethylene sachet $(50 \mathrm{~mm} \times 50 \mathrm{~mm} \times 250 \mu \mathrm{m})$, and ethanol was formulated as $1 \mathrm{~mL}$ in a polyethylene press-seal bag (76 mm $\times 57 \mathrm{~mm} \times 50 \mu \mathrm{m})$. Field catches were similar at all three study sites. Catches in traps baited with 3-hydroxy-2-hexanone alone were not significantly different from those in unbaited control traps, but catches in traps baited with 3-hydroxy-2-hexanone and ethanol in separate sachets, with 3-hydroxy-2-hexanone and ethanol in the same sachet or with ethanol alone were significantly greater than those in control traps. These results confirm that the beetles are attracted to ethanol, and the addition of 3-hydroxy-2-hexanone does not seem to make any difference.
\end{abstract}

CONCLUSIONS: Attraction of females for the male-produced compound $(R)-3$-hydroxy-2-hexanone has been observed in laboratory but not in field experiments. Traps baited with ethanol are highly attractive to both sexes of adults of $X$. arvicola, and these can be used for improved monitoring of the adult emergence and for population control by mass trapping.

(c) 2016 Society of Chemical Industry

Keywords: Xylotrechus arvicola; Cerambycidae; (R)-3-hydroxy-2-hexanone; ethanol; panel traps; monitoring

\section{INTRODUCTION}

The beetle Xylotrechus arvicola (Olivier) (Coleoptera: Cerambycidae) is a serious pest of vineyards in the Duero Valley (Iberian Peninsula). $X$. arvicola has a great capacity to establish itself in new vineyards, ${ }^{1}$ and larvae can spread fungi such as Diplodia seriata (De Not), Eutypa lata (Tul and Tul), Phaeoacremonium aleophilum (Gams, Crous, Wingf., Mugnai), Phaeomoniella chlamydospora (Crous and Gams) and Formitiporia mediterranea (Fisch) across the wood. ${ }^{2}$

After mating, females of $X$. arvicola lay their eggs in cracks or under the rhytidome in the wood of vines. ${ }^{3}$ The eggs remain viable over a long period, ${ }^{4}$ and the emerging larvae bore into the wood and make galleries inside the plant. ${ }^{5}$ The stages of the pest most susceptible to intervention are adults, eggs and neonate larvae, but the latter are usually protected by the rhytidome. ${ }^{3}$ Once inside the wood, the larvae are inaccessible to traditional foliar-applied chemicals that do not have systemic attributes. ${ }^{6}$

Insect sex pheromones are used in pest management for monitoring and control. ${ }^{7}$ Monitoring of insect pests using pheromone traps can help pest surveillance and the forecasting of optimal timing for insecticide applications (e.g. Delisle et al. $^{8}$ and Boddum et $a l^{9}{ }^{9}$. Mass trapping using pheromone traps can reduce insect pest populations, which can lead to a reduction in damage in field crops and stored products. ${ }^{7,10}$ Male-produced aggregation pheromones have been identified for several Xylotrechus species, including $X$. quadripes (Chevrolat), ${ }^{11} X$. pyrrhoderus Bates, ${ }^{12} X$. chinensis (Chevrolat), ${ }^{13}$ Xylotrechus colonus (Fabricius), ${ }^{14} X$. nauticus (Mannerheim) ${ }^{15}$ and $X$. rufilius Bates. ${ }^{16} 3$-Hydroxy-2-hexanone, the corresponding 2,3-hexanediols and the homologous 8-carbon

\footnotetext{
Correspondence to: Á Rodríguez-González, Department of Engineering and Agricultural Sciences, Environment Institute Natural Resources and Biodiversity, University of León, Portugal Avenue 41, 24071 León, Spain. E-mail:alrog@unileon.es

a Department of Engineering and Agricultural Sciences, Environment Institute Natural Resources and Biodiversity, University of León, León, Spain

b Company Esteban Sanchez Maillo, Corbeta 10, Zamora, Spain

c Freelance, Vicente Aleixandre 24, Valladolid, Spain

d Plant Protection Department, Instituto Nacional de Investigación y Tecnología Agraria y Alimentaria (INIA), Carretera de La Coruña, Madrid, Spain

e Natural Resources Institute, University of Greenwich, Chatham Maritime, Kent,
} UK 
compounds are common, and often the sole pheromone components for many species in the subfamily Cerambycinae. ${ }^{17}$ 3-Hydroxy-2-hexanone has been used as bait in traps to catch multiple species of subfamily Cerambycinae. ${ }^{15,17-20}$

In previous work by the Natural Resources Institute (NRI) and Instituto Nacional de Investigación y Tecnología Agraria y Alimentaria (INIA) during 2005-2007, X. arvicola male beetles, but not females, were shown to produce 3-hydroxy-2-hexanone. ${ }^{21}$ The beetles produced exclusively the $R$-enantiomer, and rates of production of up to $68 \mu \mathrm{g} \mathrm{h}^{-1}$ were recorded. The synthetic compound elicited electroantennographic (EAG) responses from receptors on the antennae of both males and females. In laboratory wind tunnel bioassays, females were significantly attracted to males and to $(R)$-3-hydroxy-2-hexanone or the racemic mixture, and this compound was assumed to be the major component of the sex/aggregation pheromone of this species. However, this attraction was not observed in preliminary trapping trials in the field in Spain. The aims of this work were to evaluate different types of dispenser for 3-hydroxy-2-hexanone in the laboratory, and to use these to carry out further field testing of this compound in Spanish vineyards.

\section{MATERIALS AND METHODS}

\subsection{Chemicals}

3-Hydroxy-2-hexanone was synthesised in the racemic form at the NRI by reaction of 1-hexyn-3-ol with mercuric oxide and boron trifluoride etherate in methanol, followed by acidic hydrolysis. ${ }^{22}$

For preparation of the $R$-enantiomer, the corresponding racemic acetate was hydrolysed with Amano AK lipase in phosphate buffer which selectively hydrolysed the $S$-enantiomer. ${ }^{23}$ The remaining $R$-acetate was isolated by chromatography and converted to (R)-3-hydroxy-2-hexanone ( $96 \%$ enantiomeric excess) by careful hydrolysis with potassium carbonate in methanol.

\subsection{Dispensers}

The dispensers used in this work were press-seal, low-density polyethylene bags $(76 \mathrm{~mm} \times 57 \mathrm{~mm} \times 50 \mu \mathrm{m}$ thick or $38 \mathrm{~mm}$ $\times 64 \mathrm{~mm} \times 50 \mu \mathrm{m}$ thick; Transpack, Southampton, UK), sachets prepared by heat sealing low-density, polyethylene lay-flat tubing (50 mm width $\times 250 \mu \mathrm{m}, 120 \mu \mathrm{m}$ or $60 \mu \mathrm{m}$ thick; Transpack) or low-density polyethylene vials $(30 \mathrm{~mm} \times 15 \mathrm{~mm} \times 1.5 \mathrm{~mm}$ thick; Fisher Scientific, Loughborough, UK). 3-Hydroxy-2-hexanone (100 $\mu \mathrm{L})$ was impregnated onto a cellulose acetate cigarette filter (14 mm $\times 6 \mathrm{~mm}$; Swan, High Wycombe, Bucks, UK) in all these dispensers.

The above dispensers were compared with those reported for other cerambycid beetles using pheromones dispensed from solutions in ethanol. ${ }^{24,25}$ In initial laboratory work and field experiments carried out in 2011, a solution of 3-hydroxy-2-hexanone in ethanol (50 mg in $1 \mathrm{~mL}$ ) was dispensed from press-seal, low-density polyethylene bags $(76 \mathrm{~mm} \times 57 \mathrm{~mm} \times 50 \mu \mathrm{m}$ thick; Transpack). During 2012, the same solution was impregnated onto a cotton dental roll (a cylinder of purified and sterilised cotton wool; $35 \mathrm{~mm} \times 8 \mathrm{~mm}$; Kent Express Dental Supplies, Gillingham, Kent, UK) in the bag.

\subsection{Release rates}

Release rates of materials from dispensers were generally measured by weighing duplicate samples at intervals. Dispensers were maintained in a wind tunnel at $27^{\circ} \mathrm{C}$ and $8 \mathrm{~km} \mathrm{~h}^{-1}$ wind speed, or in a laboratory fume hood at $20-22^{\circ} \mathrm{C}$.
For solutions of 3-hydroxy-2-hexanone in ethanol, a sample (10 $\mu \mathrm{L}$ ) was withdrawn at intervals and added to a solution of decyl acetate in hexane $\left(0.2 \mathrm{mg} \mathrm{mL}^{-1} ; 1 \mathrm{~mL}\right)$. The resulting solution was analysed by gas chromatography (GC) using a fused silica capillary column ( $30 \mathrm{~m} \times 0.32 \mathrm{~mm}$ i.d. $\times 0.25 \mu \mathrm{m}$ film thickness) coated with polar DBWax (Agilent, Stockport, Cheshire, UK) with flame ionisation detection (FID; $250^{\circ} \mathrm{C}$ ). Injection was splitless $\left(200^{\circ} \mathrm{C}\right)$, the carrier gas was helium $\left(2.4 \mathrm{~mL} \mathrm{~min}^{-1}\right)$ and the oven temperature was programmed from $50^{\circ} \mathrm{C}$ for $2 \mathrm{~min}$ and then at $10^{\circ} \mathrm{C} \mathrm{min}^{-1}$ to $240^{\circ} \mathrm{C}$. Data were captured and quantified using EZChrom Elite (Agilent).

\subsection{Experimental vineyards}

Field trapping tests were conducted in three experimental vineyards with Protected Denomination of Origin (PDO), which is a certification to distinguish quality food products of a particular region (UE Reg. No. 1151/2012 published on 21 November 2012), called 'Ribera Del Duero', located in Peñafiel (Valladolid), 'Toro', located in El Pego (Zamora), and 'Tierra de León', located in Gordoncillo (León). The vineyards were chosen on the basis of the presence of $X$. arvicola damage such as larval galleries inside the plants and exit holes of $X$. arvicola adults on trunks and branches. These vineyards were planted uniformly with the same Vitis vinifera Tempranillo variety. Vines were spaced $3 \times 1.5 \mathrm{~m}$ in 'Ribera Del Duero' and 'Tierra de León', and $3.5 \times 3.5 \mathrm{~m}$ in 'Toro'. Vineyards were surrounded by other vineyards. More details of the experimental vineyards are shown in Table 1.

\subsection{Traps, lures and experimental design}

The traps used were the CROSSTRAP ${ }^{\circledR}$ design (Econex, Murcia, Spain). This trap is made of two black panels of Correx sheet (80 $\mathrm{cm} \times 30 \mathrm{~cm}$ ) held at right angles. Unless otherwise stated, the panels were coated with Fluon (DYNEON ${ }^{\mathrm{TM}} ; 3 \mathrm{M}^{\mathrm{TM}}$, Berkshire, UK), as recommended by Graham et al. ${ }^{26}$ The lures were attached to the trap at the midway point, and insects were trapped in a receiver at the base. The collected insects were identified and sexed in the laboratory, according to the description of Moreno. ${ }^{27}$ In all experimental vineyards, there were four replicates of each treatment in a randomised complete block design, including an unbaited control. Traps were spaced at $18 \mathrm{~m}$ intervals, approximately 1.5 $\mathrm{m}$ above ground level, and treatments were randomised within blocks. Traps were visited every $2-3$ days, when trapped beetles were counted and removed. Lures were renewed every 10 days. To avoid spatial effects, the traps were moved on one position every 10 days.

Three sets of treatments were evaluated during 2011 and 2012, and these are shown in Table 2. During 2011, racemic and $(R)$-3-hydroxy-2-hexanone dispensed neat in sachets were compared with an ethanolic solution of the racemic compound in a press-seal bag. Traps with and without Fluon coating were compared to confirm the value of this treatment. In 2012, racemic 3-hydroxy-2-hexanone in sachets was compared with the racemic compound in ethanol solution in press-seal bags and with ethanol alone. In a final experiment during 2012 at 'Tierra de León', catches with ethanol alone were compared with those in unbaited traps.

\subsection{Statistical analysis}

For statistical analyses, total numbers of beetles trapped were transformed to $\log (x+1)$ to normalise the variances and subjected to analysis of variance (ANOVA). Differences between means were 
Table 1. Details of experimental vineyards with PDO

\begin{tabular}{|c|c|c|c|}
\hline & 'Ribera Del Duero' & 'Toro' & 'Tierra de León' \\
\hline Location & Peñafiel & El Pego & Gordoncillo \\
\hline Province & Valladolid & Zamora & León \\
\hline Coordinates & $41^{\circ} 35^{\prime} 39.1^{\prime \prime} \mathrm{N}, 4^{\circ} 05^{\prime} 19.1^{\prime \prime} \mathrm{W}$ & $41^{\circ} 20^{\prime} 26.4^{\prime \prime} \mathrm{N}, 5^{\circ} 25^{\prime} 51.8^{\prime \prime} \mathrm{W}$ & $42^{\circ} 08^{\prime} 14.9^{\prime \prime} \mathrm{N}, 5^{\circ} 25^{\prime} 41.6^{\prime \prime} \mathrm{W}$ \\
\hline Height above sea level (m) & 754 & 697 & 747 \\
\hline $\begin{array}{l}\text { Annual average } \\
\text { temperature }\left({ }^{\circ} \mathrm{C}\right)\end{array}$ & 11 & 12.5 & 11.7 \\
\hline Average rainfall $(\mathrm{mm})$ & 450 & 375 & 500 \\
\hline Soils & $\begin{array}{l}\text { Alluvial sand and clay soils in low } \\
\text { areas, limestone soils and chalk } \\
\text { in high areas }\end{array}$ & $\begin{array}{l}\text { Calcareous soils formed by } \\
\text { sandstone, clay and limestone } \\
\text { sediments }\end{array}$ & $\begin{array}{l}\text { Calcareous soils, low in minerals } \\
\text { and poor in organic matter }\end{array}$ \\
\hline Training system of vines & Bilateral cordon & Bush vines & Bilateral cordon \\
\hline $\begin{array}{l}\text { Training system } \\
\text { characteristics }\end{array}$ & $\begin{array}{l}\text { Spur pruning over two arms per } \\
\text { trunk }(1 \mathrm{~m})\end{array}$ & $\begin{array}{l}\text { Spur pruning over } 4-5 \text { branches } \\
\text { per trunk }(0.5 \mathrm{~m})\end{array}$ & $\begin{array}{l}\text { Spur pruning over two arms per } \\
\text { trunk }(1 \mathrm{~m})\end{array}$ \\
\hline Vitis vinifera variety & 'Tempranillo' & 'Tempranillo' & 'Tempranillo' \\
\hline Age (years) & 25 & 50 & 18 \\
\hline
\end{tabular}

\begin{tabular}{|c|c|c|}
\hline Year & PDO name - location (province) & Treatments $^{\mathrm{a}}$ \\
\hline \multirow[t]{5}{*}{2011} & 'Ribera Del Duero' - Peñafiel (Valladolid) & 3-Hydroxy-2-hexanone in sachet \\
\hline & 'Toro' - El Pego (Zamora) & 3-Hydroxy-2-hexanone in sachet (trap without Fluon) \\
\hline & & Unbaited control \\
\hline & & 3-Hydroxy-2-hexanone in ethanol solution in press-seal bag \\
\hline & & (R)-3-Hydroxy-2-hexanone in sachet \\
\hline \multirow[t]{5}{*}{2012} & 'Ribera Del Duero' - Peñafiel (Valladolid), & 3-Hydroxy-2-hexanone in sachet \\
\hline & 'Toro' - El Pego (Zamora) & 3-Hydroxy-2-hexanone in sachet + ethanol in press-seal bag \\
\hline & 'Tierra de León' - Gordoncillo (León) & Unbaited control \\
\hline & & 3-Hydroxy-2-hexanone in ethanol solution in press-seal bag ${ }^{b}$ \\
\hline & & Ethanol in press-seal bag ${ }^{b}$ \\
\hline \multirow[t]{5}{*}{2012} & 'Tierra de León' - Gordoncillo (León) & A3: ethanol in press-seal bag ${ }^{b}$ \\
\hline & & B3: ethanol in press-seal bag ${ }^{b}$ \\
\hline & & C3: ethanol in press-seal bag ${ }^{b}$ \\
\hline & & D3: ethanol in press-seal bag ${ }^{b}$ \\
\hline & & E3: ethanol in press-seal bag ${ }^{b}$ \\
\hline
\end{tabular}

tested for significance by the least significant difference (LSD) test. The level of significance considered was $P<0.05$ in all cases.

\section{RESULTS}

\subsection{Release rates}

Release rate data are summarised in Table 3 . Release rates of 3-hydroxy-2-hexanone from press-seal bags $(76 \mathrm{~mm} \times 57 \mathrm{~mm} \times 50$ $\left.\mu \mathrm{m} ; 86.6 \mathrm{~cm}^{2}\right)$ and heat-sealed sachets $(50 \mathrm{~mm} \times 50 \mathrm{~mm} \times 120 \mu \mathrm{m}$; $50 \mathrm{~cm}^{2}$ ) were rapid at 17.9 and $11.4 \mathrm{mg} \mathrm{day}^{-1}$ respectively. Release from a thinner $60 \mu \mathrm{m}$ sachet was even more rapid at $19.4 \mathrm{mg} \mathrm{day}^{-1}$.

Reducing the size of the dispensers reduced the release rate as expected. A smaller press-seal bag ( $38 \mathrm{~mm} \times 64 \mathrm{~mm} \times 50 \mu \mathrm{m} ; 48.6$ $\mathrm{cm}^{2}$ ) released at a rate of $11.5 \mathrm{mg} \mathrm{day}^{-1}$, and half-size sachets ( 25 $\mathrm{mm} \times 50 \mathrm{~mm} \times 120 \mu \mathrm{m} ; 25 \mathrm{~cm}^{2}$ ) at approximately $7 \mathrm{mg} \mathrm{day}^{-1}$. Increasing the length of the sachet from 50 to $90 \mathrm{~mm}$ increased the release rate from 6.5 to $7.1 \mathrm{mg} \mathrm{day}^{-1}$. Increasing the thickness of the sachet reduced the release rate as expected, with a $50 \mathrm{~mm}$ $\times 50 \mathrm{~mm} \times 250 \mu \mathrm{m}$ sachet releasing at a rate of $4.4 \mathrm{mg} \mathrm{day}^{-1}$.
Release of 3-hydroxy-2-hexanone from a polyethylene vial was much slower. There was no release for the first 3 days as the material passed through the walls, but thereafter release was uniform at $0.23 \mathrm{mg} \mathrm{day}^{-1}$.

Release of ethanol from a press-seal bag $(76 \mathrm{~mm} \times 57 \mathrm{~mm} \times 50$ $\mu \mathrm{m}$ thick) was linear at $38.6 \mathrm{mg}$ day $^{-1}$ at $20-22^{\circ} \mathrm{C}$. Release from all these 'reservoir-type' dispensers was zero order and continued until the contents were exhausted.

When a solution of 3-hydroxy-2-hexanone $(50 \mathrm{mg})$ in ethanol $(1 \mathrm{~mL})$ was formulated in a press-seal bag $(76 \mathrm{~mm} \times 57 \mathrm{~mm}$ $\times 50 \mu \mathrm{m})$, the ethanol was released at $86 \mathrm{mg} \mathrm{day}^{-1}$ at $27{ }^{\circ} \mathrm{C}$. Analysis of the solution remaining at daily intervals showed that the concentration of 3-hydroxy-2-hexanone remained essentially the same $\left[50.0 \pm 1.2\right.$ (SE) $\mathrm{mg} \mathrm{mL}^{-1}$ at day $0,47.0 \pm 1.8 \mathrm{mg} \mathrm{mL}^{-1}$ at day $7, N=3]$, indicating that this compound was released in proportion, i.e. at $5.7 \mathrm{mg} \mathrm{day}^{-1}$.

Impregnating the ethanolic solution of 3-hydroxy-2-hexanone on a cotton dental roll caused a slight but not significant reduction in release rate $(N=4 ; t=1.56, \mathrm{df}=4, P=0.08)$. These results 
Table 3. Release rates of 3-hydroxy-2-hexanone and ethanol from different dispensers in the laboratory

\begin{tabular}{|c|c|c|c|c|}
\hline Compound & Dispenser & Dimensions & Temperature $\left({ }^{\circ} \mathrm{C}\right)$ & Rate $\left(\mathrm{mg} \mathrm{day}^{-1}\right)^{\mathrm{a}}$ \\
\hline \multirow{8}{*}{$\begin{array}{l}\text { 3-Hydroxy-2- } \\
\text { hexanone }\end{array}$} & Press-seal bag & $76 \mathrm{~mm} \times 57 \mathrm{~mm} \times 50 \mu \mathrm{m}$ & 27 & $17.9 \pm 0.6$ \\
\hline & Press-seal bag & $38 \mathrm{~mm} \times 64 \mathrm{~mm} \times 50 \mu \mathrm{m}$ & 27 & $11.5 \pm 0.2$ \\
\hline & Sachet & $50 \mathrm{~mm} \times 50 \mathrm{~mm} \times 60 \mu \mathrm{m}$ & 27 & $19.4 \pm 0.3$ \\
\hline & Sachet & $50 \mathrm{~mm} \times 50 \mathrm{~mm} \times 120 \mu \mathrm{m}$ & 27 & $11.4 \pm 0.2$ \\
\hline & Sachet & $50 \mathrm{~mm} \times 50 \mathrm{~mm} \times 250 \mu \mathrm{m}$ & 27 & $4.4 \pm 0.04$ \\
\hline & Sachet & $25 \mathrm{~mm} \times 50 \mathrm{~mm} \times 120 \mu \mathrm{m}$ & 27 & $6.5 \pm 0.1$ \\
\hline & Vial & $30 \mathrm{~mm} \times 15 \mathrm{~mm} \times 1.5 \mathrm{~mm}$ & 27 & $0.2 \pm 0.0$ \\
\hline & $\begin{array}{l}\text { Press-seal bag } \\
\quad\left(50 \mathrm{mg} \mathrm{mL}^{-1} \text { in ethanol) }\right.\end{array}$ & $76 \mathrm{~mm} \times 57 \mathrm{~mm} \times 50 \mu \mathrm{m}$ & 27 & $5.7 \pm 0.4^{b}$ \\
\hline \multirow[t]{2}{*}{ Ethanol } & Press-seal bag & $76 \mathrm{~mm} \times 57 \mathrm{~mm} \times 50 \mu \mathrm{m}$ & 27 & $86.0 \pm 6.1^{b}$ \\
\hline & Press-seal bag & $76 \mathrm{~mm} \times 57 \mathrm{~mm} \times 50 \mu \mathrm{m}$ & $20-22$ & $38.6 \pm 3.0$ \\
\hline
\end{tabular}

were obtained by heat-sealing the press-seal bags. Without heat sealing, release rates sometimes differed markedly between otherwise identical dispensers, probably because of difficulties in reliably sealing the bags containing the solution. Impregnating the solution on a dental roll gave consistent release rates without the need for heat sealing.

In view of these laboratory results, for field trials 3-hydroxy2-hexanone was formulated as $100 \mu \mathrm{L}$ in a heat-sealed, thick polyethylene sachet $(50 \mathrm{~mm} \times 50 \mathrm{~mm} \times 250 \mu \mathrm{m})$, and ethanol was formulated as $1 \mathrm{~mL}$ in a press-seal bag ( $76 \mathrm{~mm} \times 57 \mathrm{~mm} \times 50 \mu \mathrm{m})$. The dispensers were renewed every 10 days in field experiments, as described in Section 2.

\subsection{Field trial 2011}

Catches of $X$. arvicola beetles in traps (Fig. 1) baited with 3-hydroxy-2-hexanone alone dispensed from polyethylene sachets either in the racemic form (treatments $A 1$ and $B 1$ ) or as the $R$-enantiomer (E1) were not significantly different $(P>0.05)$ from those in control traps at 'Ribera del Duero'. However, catches in traps baited with 3-hydroxy-2-hexanone formulated as a solution in ethanol in press-seal bags (D1) were significantly higher. Catches in traps without Fluon coating (B1) were significantly lower than those in comparable traps coated with Fluon (A1). Results were similar at 'Toro' (Fig. 1), but catches were lower and differences between the treatments were not so marked. Catches were 50:50 male:female at 'Ribera del Duero' and 53:47 at 'Toro' (Fig. 1).

\subsection{Field trial 2012}

The results of the first experiment were similar at all three sites, and the combined results are shown in Fig. 2. Catches of $X$. arvicola beetles in traps baited with 3-hydroxy-2-hexanone alone (A2) were not significantly different from those in unbaited control traps (C2). Catches in traps baited with 3-hydroxy-2-hexanone and ethanol in separate sachets (B2), with 3-hydroxy-2-hexanone and ethanol in the same sachet (D2) or with ethanol alone (E2) were significantly greater $(P<0.05)$ than those in control traps (C2). These results confirm that the beetles are attracted to ethanol (E2), and the addition of 3-hydroxy-2-hexanone (B2 and D2) does not seem to make any difference.

At 'Tierra de León', the final week of the experiment was run with treatments $A 3, B 3$ and $D 3$ replaced by sachets of ethanol only,



Figure 1. Mean total catches of $X$. arvicola beetles at 'Ribera del Duero' - Peñafiel (Valladolid) and 'Toro' - El Pego (Zamora) during 2011 (4 June-4 July). Treatments - A1: 3-hydroxy-2-hexanone in sachet; B1: 3-hydroxy-2-hexanone in sachet (trap without Fluon); C1: unbaited control; D1: 3-hydroxy-2-hexanone in ethanol solution in press-seal bag; E1: (R)-3-hydroxy-2-hexanone in sachet. For each location, means with different letters are significantly different at $P<0.05$ after ANOVA and LSD test ('Ribera del Duero': $F=15.19, \mathrm{df}=4,12, P<0.001$; 'Toro': $F=3.82, \mathrm{df}=4$, $12, P=0.03)$.

as in E3. High catches of $X$. arvicola were obtained in the baited traps during 22-28 June 2012, and these were very significantly greater than catches in the control traps by a simple $t$-test on untransformed data (Fig. 3).

\section{DISCUSSION}

3-Hydroxy-2-hexanone is produced by males of many cerambycid species, particularly those in the Cerambycinae subfamily, and in many of these it has been shown to function as a sex/aggregation pheromone. $^{17}$

In order to evaluate a potential pheromone in the field effectively, it is essential to use dispensers releasing the compound at an appropriate rate as uniformly as possible for the duration of the experiment. Several slow-release formulations of this candidate pheromone component were evaluated in the laboratory, and a thick-walled polyethylene sachet made from heat-sealed, lay-flat tubing was shown to be a suitable dispenser with a zero-order release rate of $4.4 \mathrm{mg} \mathrm{day}^{-1}$, comparable with the rate of production by a male $X$. arvicola beetle of $68 \mu \mathrm{g} \mathrm{h}^{-1}\left(1.6 \mathrm{mg} \mathrm{day}^{-1}\right) .^{21}$

The dispensing system used in many other studies of pheromones of cerambycid beetles (e.g. Ray et al. ${ }^{24}$ and Rodstein 




Figure 2. Mean total catches of $X$. arvicola beetles at 'Ribera del Duero' - Peñafiel (Valladolid), 'Toro' - El Pego (Zamora) and 'Tierra de León' - Gordoncillo (León) during 2012 (18 May-18 June 2012). Treatments - A2: 3-hydroxy-2-hexanone in sachet; B2: 3-hydroxy-2-hexanone in sachet + ethanol in press-seal bag; C2: unbaited control; D2: 3-hydroxy-2-hexanone in ethanol solution in press-seal bag; E2: ethanol in press-seal bag. For each category, means with different letters are significantly different $(P<0.05)$ after ANOVA and LSD test (males: $F=4.58$, $\mathrm{df}=4,44, P=0.003$; females: $F=5.31, \mathrm{df}=4,44, P<0.001$; combined: $F=$ $6.86, \mathrm{df}=4,44, P<0.001)$.

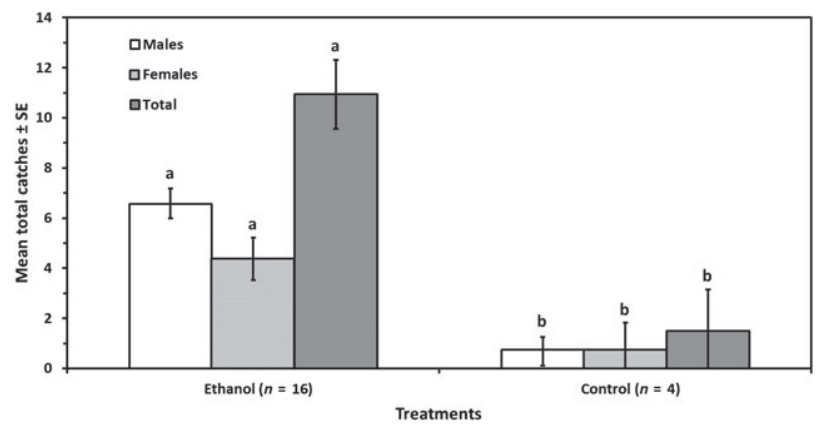

Figure 3. Mean total catches of $X$. arvicola beetles at 'Tierra de León' - Gordoncillo (León) during 2012 (18-28 June) in traps baited with ethanol alone or in unbaited control traps. Means with different letters are significantly different at $P<0.001$ after $t$-test (males: $t=6.75, \mathrm{df}=16, P<$ 0.001 ; females: $t=4.91, \mathrm{df}=12, P<0.001$; combined: $t=8.30, \mathrm{df}=12, P<$ $0.001)$.

et $a .^{25}$ ) was included in these studies. This consisted of the pheromone dissolved in ethanol in a press-seal polyethylene bag. The release rate of the pheromone from these systems has not previously been reported because the concomitant release of ethanol makes it difficult to measure by weight loss and also potentially affects the adsorptive properties of adsorbents used in dynamic headspace trapping. Here the release rate was calculated by assaying the concentration of 3-hydroxy-2-hexanone in the ethanol solution remaining by gas chromatography after various intervals of exposure and by determining the amount of ethanol remaining. Rates for the ethanol and 3-hydroxy-2-hexanone were 86 and $5.7 \mathrm{mg} \mathrm{day}^{-1}$ respectively at $27^{\circ} \mathrm{C}$, the latter being of a similar order to that from the polyethylene sachet. It was also found that release rates from the press-seal bags containing the solutions were very erratic, probably because of difficulties in reliably sealing the bags. Impregnating the solution on a dental roll in the bag gave more consistent release rates, as reported recently by Hanks and Millar, ${ }^{17}$ and the studies here showed there was no significant effect on the release rate of ethanol.

Field trapping tests carried out over two seasons at three sites in Spain failed to demonstrate any attraction of $X$. arvicola beetles to 3-hydroxy-2-hexanone, but significant numbers of beetles were attracted to the compound in ethanol and to ethanol alone. Lack of attraction of $X$. arvicola adults to traps baited with ( $R$ )-3-hydroxy-2-hexanone was unexpected, considering that it is produced in large quantities by the male beetles, and that some attraction had been observed in laboratory bioassays. ${ }^{21}$ This may be because other pheromone components are required, although the corresponding 2,3-hexanediols or the 8 -carbon homologues could not be detected in volatile collections from males (González-Núñez $M$ and Hall DR, unpublished data). Other, unrelated compounds may be required to synergise the male-produced compound, as reported for Callidiellum rufipenne (Motschulsky) (Coleoptera: Cerambycidae), the males of which also produce $(R)$-3-hydroxy-2-hexanone. ${ }^{28}$ It may be that the pheromone is only attractive in the presence of key host-plant volatiles, although in other cerambycid species where the attractiveness of the pheromone is synergised by host-plant volatiles the pheromone alone shows significant attraction (e.g. Pajares et al. ${ }^{29}$ and Collignon et al..$^{30}$ ). Other examples of this lack of attractiveness of compounds produced by male cerambycid beetles, particularly 3-hydroxy-2-hexanone, have been reported recently by Hanks and Millar. ${ }^{17}$

Attraction of beetles to ethanol is by no means unprecedented, and other cerambycids have been attracted by combinations of pheromones and host-plant volatiles, including ethanol. ${ }^{31-34}$ Xylotrechus species are reported to be attracted to stressed and weakened plants, ${ }^{35}$ and it is likely that these would produce ethanol. Ethanol emissions have been shown to increase in trees after a stress event, ${ }^{36-39}$ and thus some cerambycids probably use ethanol to locate stressed host trees, even in the absence of pheromone signals. ${ }^{33}$

The field experiments also confirmed that black panel traps are suitable for capture of $X$. arvicola. Rodríguez-González et al. ${ }^{40}$ evaluated different trap types for capture of $X$. arvicola adults, and showed that the black panel trap was significantly better than the other two types of trap tested, delta and screen adhesive. Coating the panels with Fluon also improved catches, as reported by Graham et al. ${ }^{26}$

\section{CONCLUSIONS}

Although in previous studies females showed attraction by 3-hydroxy-2-hexanone in wind tunnel tests, to date no attraction has been demonstrated in field experiments. However, it has been shown that black panel traps baited with ethanol are highly attractive to both sexes of adults of $X$. arvicola, and these traps can be used for improved monitoring of the emergence of the adult beetles and perhaps even for controlling them.

\section{ACKNOWLEDGEMENTS}

This study was carried out as part of a project (Xylotrechus arvicola, técnicas de seguimiento y control en el cultivo de la vid; VA/090137/S21) financed by the Rural Development Programme in Castilla y León, cofinanced by the European Agricultural Fund for Rural Development (FEADER) and 'Pago de Carraovejas' wine cellar.

\section{REFERENCES}

1 Rodríguez-González A, Improvement in control strategies of cerambycids in vine growing. PhD thesis, University of León, León, Spain (2014). 
2 García-Benavides P, Martin-Zamorano P, Ocete-Pérez CA, Maistrello L and Ocete R, Biodiversity of pathogenic wood fungi isolated from Xylotrechus arvicola (Olivier) galleries in vine shoots. J Int Sci Vigne Vin 47:73-81 (2013).

3 Peláez H, Hernández JM, Martín MC, Moreno CM and Santiago Y, Determinación de las características del huevo de Xylotrechus arvicola (Coleoptera: Cerambycidae, Olivier, 1795). Libro de Actas del X Congreso lbérico de Entomología, Zamora, Spain, p. 52 (2002).

4 Rodríguez-González A, Peláez HJ, González-López O, Mayo S and Casquero PA, Reproductive patterns of Xylotrechus arvicola (Coleoptera: Cerambycidae), and emerging pest of grape-vines, under laboratory conditions. J Econ Entomol 109:1226-1230 (2016).

5 García Ruiz E, Contribución al Manejo de Plagas en vid: Xylotrechus arvicola Olivier (Coleoptera: Cerambycidae) y Lobesia botrana Denis \& Schiffermüller (Lepidoptera: Tortricidae). PhD thesis, University of La Rioja, Logroño, Spain (2009).

6 Rodríguez-González A, Peláez HJ, Mayo S, González-López O and Casquero PA, Egg development and toxicity of insecticides to eggs, neonate larvae and adults of Xylotrechus arvicola, a pest in Iberian grapevines. Vitis 55:83-93 (2016).

7 Witzgall $\mathrm{P}$, Kirsch $\mathrm{P}$ and Cork A, Sex pheromones and their impact on pest management. J Chem Ecol 36:80-100 (2010).

8 Delisle J, West RJ and Bowers WW, The relative performance of pheromone and light traps in monitoring the seasonal activity of both sexes of the eastern hemlock looper, Lambdina fiscellaria fiscellaria. Agric Ecosyst Environ 89:87-98 (1998).

9 Boddum T, Skals N, Wirén M, Baur R, Rauscher S and Hillbur Y, Optimisation of the pheromone blend of the swede midge, Contarinia nasturtii, for monitoring. Pest Manag Sci 65:851-856 (2009).

10 El-Sayed AM, Suckling DM, Wearing CH and Byers JA, Potential of mass trapping for long-term pest management and eradication of invasive species. J Econ Entomol 99:1550-1564 (2006).

11 Hall DR, Cork A, Phythian SJ, Chittamuru S, Jayarama BK, Venkatesha MG et al., Identification of components of male-produced pheromone of coffee white stemborer, Xylotrechus quadripes. J Chem Ecol 32:195-219 (2006).

12 Sakai T, Nakagawa Y, Takahashi J, Iwabuchi K and Ishii K, Isolation and identification of the male sex pheromone of the grape borer Xylotrechus pyrrhoderus Bates (Coleoptera: Cerambycidae). Chem Lett 84:263-264 (1984).

13 Kuwahara $\mathrm{Y}$, Matsuyama $\mathrm{S}$ and Suzuki T, Identification of 2,3octanediol, 2-hydroxy-3-octanone and 3-hydroxy-2-octanone from male Xylotrechus chinensis Chevrolat as possible sex pheromones (Coleoptera: Cerambycidae). Appl Entomol Zool 22:25-28 (1987).

14 Lacey ES, Millar JG, Moreira JA and Hanks LM, Male-produced aggregation pheromones of the cerambycid beetles Xylotrechus colonus and Sarosesthes fulminans. J Chem Ecol 35:733-740 (2009).

15 Hanks LM, Millar JG, Moreira JA, Barbour JD, Lacey ES, McElfresh JS et al., Using generic pheromone lures to expedite identification of aggregation pheromones for the cerambycid beetles Xylotrechus nauticus, Phymatodes lecontei, and Neoclytus modestus modestus. J Chem Ecol 35:96-103 (2007).

16 Narai Y, Zou Y, Nakamuta K, Mongold-Diers JA, Hanks LM and Millar JG, Candidate attractant pheromones of two potentially invasive Asian Cerambycid species in the genus Xylotrechus. J Econ Entomol 108:1444-1446 (2015).

17 Hanks LM and Millar JG, Sex and aggregation-sex pheromones of cerambycid beetles: basic science and practical applications. J Chem Ecol 42:631-654 (2016)

18 Hanks LM, Millar JG, Mongold-Diers JA, Wong JCH, Meier LR and Reagel $\mathrm{PF}$, Using blends of cerambycid beetle pheromones and host plant volatiles to simultaneously attract a diversity of cerambycid species. Can J For Res 42:1050-1059 (2012).

19 Hanks LM and Millar JG, Field bioassays of cerambycid pheromones reveal widespread parsimony of pheromone structures, enhancement by host plant volatiles, and antagonism by components from heterospecifics. Chemoecology 23:21-44 (2012).

20 Wong JCH, Mitchell RF, Striman BL, Millar JG and Hanks LM, Blending synthetic pheromones of cerambycid beetles to develop trap lures that simultaneously attract multiple species. J Econ Entomol 105:906-915 (2012).
21 Hall D, Esteban-Durán JR, Armendáriz I, Farman D, Amarawardana L, Miranda L et al., Investigación de los mecanismos de atracción feromonal de Xylotrechus arvicola (Olivier) (Coleoptera: Cerambycidae). $\checkmark$ Congreso Nacional de Entomología Aplicada. XI Jornadas Científicas de la Sociedad Española de Entomología Aplicada, Cartagena, Spain, p. 83 (2007).

22 Leal WS, Shi X, Nakamuta K, Ono M and Meinwald J, Structure, stereochemistry and thermal isomerization of the male sex pheromone of the longhorn beetle, Anaglyptus subfasciatus. Proc Natl Acad Sci USA 92:1038-1142 (1995).

23 Lacey ES, Moriera JA, Millar JG, Ray AM and Hanks LM, Male produced aggregation pheromone of the cerambycid beetle Neoclytus mucronatus mucronatus. Entomol Exp App/ 122:171 - 179 (2007).

24 Ray AM, Millar JG, McElfresh JS, Swift IP, Barbour JD and Hanks LM, Male-produced aggregation pheromone of the cerambycid beetle Rosalia funebris. J Chem Ecol 35:96-103 (2009).

25 Rodstein J, McElfresh JS, Barbour JD, Ray AM, Hanks LM and Millar JG, Identification and synthesis of a female-produced sex pheromone for the cerambycid beetle Prionus californicus. J Chem Ecol 35:590-600 (2009).

26 Graham EE, Mitchell RF, Reagel PF, Barbour JD, Millar JG and Hanks LM, Treating panel traps with a fluoropolymer enhances their efficiency in capturing cerambycid beetles. J Econ Entomol 103:641-647 (2010).

27 Moreno CM, Xylotrechus arvicola (Olivier 1795) (Coleóptera: Cerambycidae): descripción morfológica, ciclo biológico, incidencia y daños en el cultivo de la vid. PhD thesis, ITACYL, Valladolid, Spain (2005).

28 Zou Y, Rutledge CE, Nakamuta K, Maier CT, Hanks LM, Richards AB et al., Identification of a pheromone component and a critical synergist for the invasive beetle Callidiellum rufipenne (Coleoptera: Cerambycidae). Environ Entomol 45:216-222 (2016).

29 Pajares JA, Álvarez G, Ibeas F, Gallego D, Hall DR and Farman DI, Identification and field activity of a male-produced aggregation pheromone in the pine sawyer beetle, Monochamus galloprovincialis. J Chem Ecol 36:570-583 (2010).

30 Collignon RW, Swift IP, Zou Y, McElfresh JS, Hanks LM and Millar JG, The influence of host plant volatiles on the attraction of longhorn beetles to pheromones. J Chem Ecol 42:215-229 (2016).

31 Champlain $A B$ and Knull JN, Fermenting baits for trapping Elateridae and Cerambycidae (Coleop.). Entomol News J 43:253-257 (1932).

32 Dunn JP and Potter DA, Synergistic effects of oak volatiles with ethanol in the capture of saprophagous wood borers. J Entomol Sci 26:425-429 (1991).

33 Ginzel MD and Hanks LM, Role of host plant volatiles in mate location for three species of longhorned beetles. J Chem Ecol 31:213-217 (2005).

34 Miller DR, Crowe CM, Mayo PD, Silk PJ and Sweeney JD, Responses of Cerambycidae and other insects to traps baited with ethanol, 2,3-hexanediol, and 3,2-hydroxyketone lures in North-Central Georgia. J Econ Entomol 108:2354-2365 (2015).

35 Hanks LM, Influence of the larval host plant on reproductive strategies of cerambycid beetles. Annu Rev Entomol 44:483-505 (1999).

36 Gara RI, Littke WR and Rhoades DF, Emission of ethanol and monoterpenes by fungal infected lodgepole pine trees. Phytochemistry 34:987-990 (1993).

37 Kimmerer T and Kozlowski T, Ethylene, ethane, acetaldehyde, and ethanol-production by plants under stress. Plant Physiol 69:840-847 (1982).

38 Kelsey RG, Ethanol synthesis in Douglas-fir logs felled in November, January, and March and its relationship to ambrosia beetle attack. Can J For Res 24:2096-2104 (1994).

39 Kelsey RG, Gallego D, Sánchez-García FJ and Pajares JA, Ethanol accumulation during severe drought may signal tree vulnerability to detection and attack by bark beetles. Can J For Res 44:554-561 (2014).

40 Rodríguez-González A, Mayo S, González-López O, Da Silva PH, Peláez $\mathrm{HJ}$, Sánchez E et al., Evaluation of different trap types for capture in field of Xylotrechus arvicola (Coleóptera: Cerambycidae), new pest in the vineyards (Vitis vinifera). 18th Int Plant Prot Congr (IPPC), Berlin, Germany, p. 761 (2015). 